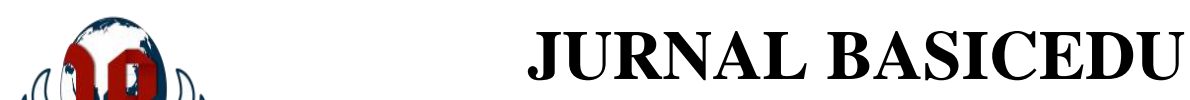

Volume 5 Nomor 4 Tahun 2021 Halaman 2036 - 2044

Research \& Learning in Elementary Education

https://jbasic.org/index.php/basicedu

PAHLAWAN

\title{
Pengembangan E-Book Cerita Bergambar Proses Terjadinya Hujan untuk Meningkatkan Minat Membaca Siswa di Sekolah Dasar
}

\author{
Novita Agnes Putrislia ${ }^{1 凶}$, Gamaliel Septian Airlanda ${ }^{2}$ \\ Universitas Kristen Satya Wacana, Indonesia ${ }^{1,2}$

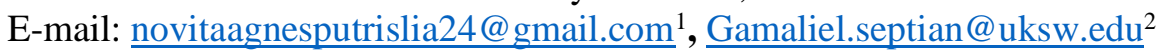

\begin{abstract}
Abstrak
Penelitian ini bertujuan untuk mengembangkan media pembelajaran e-book cerita bergambar untuk meningkatkan minat membaca siswa kelas 3 SD. Jenis penelitian ini adalah penelitian dan pengembangan (R\&D). Dari hasil studi pendahuluan, media pembelajaran yang digunakan guru hanya media cetak sehingga membuat siswa kurang tertarik dan mudah bosan saat membaca dalam pembelajaran daring. Berdasarkan hasil pendahuluan penulis bermaksud untuk mengembangkan produk $e$-book cerita bergambar yang berjudul "Proses Terjadinya Hujan" untuk meningkatkan minat membaca siswa kelas 3 SD. Draf produk diuji oleh 3 Ahli materi dan 3 Ahli media. Hasil dari validasi ahli materi pertama memperoleh skor 93\%, ahli materi kedua memperoleh skor 92\% termasuk dalam kategori "Sangat Tinggi". Hasil dari validasi ahli materi ketiga memperoleh skor $80 \%$ tergolong dalam kategori "Tinggi". Hasil dari validasi ahli media pertama memperoleh skor $88 \%$, ahli media kedua memperoleh skor $100 \%$ dan ahli media ketiga memperoleh skor $100 \%$ yang tergolong dalam kategori "Sangat Tinggi".
\end{abstract}

Kata Kunci: media pembelajaran, e-book cerita bergambar, minat membaca.

\begin{abstract}
The aims of this study is to develop a picture story e-book learning media to increase reading interest in $3 r d$ grade elementary school students. The type of the research is Research and Development $(R \& D)$. From the results of the preliminary study, manipulative tools that used by the teacher has only printed media that made students less interested and easily bored when reading in online learning. Based on the preliminary results, the author intends to develop a picture story e-book product entitled "The Process of Rain" to increase the reading interest of 3rd-grade elementary school students. Product drafts are tested by 3 Material Experts and 3 Media Experts. The results of the validation from the first material expert obtained a score of 93\%, second material expert obtained a score of 92\%, included the "Very High" category. The results of third material expert validation obtained a score of $80 \%$ belonging "High" category. The results of the validation of the first media expert obtained a score of $88 \%$, the second media expert obtained a score of $100 \%$ and the third media expert obtained a score of $100 \%$ which was included "Very High" category.
\end{abstract}

Keywords: learning media, illustrated story e-books, reading interest.

Copyright (c) 2021 Novita Agnes Putrislia, Gamaliel Septian Airlanda

Corresponding author :

Email : novitaagnesputrislia24@gmail.com

DOI : https://doi.org/10.31004/basicedu.v5i4.1032

ISSN 2580-3735 (Media Cetak)

ISSN 2580-1147 (Media Online)

Jurnal Basicedu Vol 5 No 4 Tahun 2021

p-ISSN 2580-3735 e-ISSN 2580-1147 
2037 Pengembangan E-Book Cerita Bergambar Proses Terjadinya Hujan untuk Meningkatkan Minat Membaca Siswa di Sekolah Dasar - Novita Agnes Putrislia, Gamaliel Septian Airlanda

DOI: https://doi.org/10.31004/basicedu.v5i4.1032

\section{PENDAHULUAN}

Membaca merupakan sarana untuk mempelajari suatu hal sehingga bisa memperluas pengetahuan dan menggali pesan-pesan tertulis dalam bahan bacaan yang akhirnya dapat dituangkan dalam bentuk tulisan yaitu menulis" (Dafit, 2017). (Laily, 2014)berpendapat bahwa "Kemampuan membaca pemahaman yang dimiliki seseorang bukanlah merupakan kemampuan yang turun-temurun, melainkan hasil proses belajar mengajar yang dilakukan dengan tekun dan terlatih". Minat membaca akan timbul dikalangan anak-anak ketika mereka menemukan buku yang menarik dan mengandung pengetahuan penting dalam buku, dengan itu anak-anak menjadi terlatih dan tekun saat membaca. "Membaca merupakan kunci pengetahuan dan perangkat penting menuju kemajuan dan kesuksesan" (Farid Ahmadi, 2010). "Membaca merupakan bentuk pelafalan dari suatu lambang, simbol, atau pola sehingga dapat diambil makna dari bentuk atau pola tersebut. Segala bentuk bahan bacaan yang baik akan memberikan pengetahuan bagi pembaca"(Hapsari et al., 2019).

Kemajuan ilmu pengetahuan dan teknologi mendorong perubahan dalam berbagai aspek, termasuk salah satunya adalah perubahan alat bantu mengajar ke era digital. Media pembelajaran menjadi salah satu faktor yang menyumbangkan suksesnya sebuah kegiatan pembelajaran. (Ratnasari \& Zubaidah, 2019). Namun, salah satu yang belum terlihat dan diterapkan dalam proses pembelajaran di sekolah yaitu pemberian materi pembelajaran dengan buku digital. Saat kelas 3 "peserta didik sudah mampu mengoperasikan komputer/smartphone dan konten yang mereka akses begitu familiar dalam internet, namun belum tentu memiliki edukasi yang baik." (Herlina et al., 2019). (Achmad et al., 2018)juga mengungkapkan bahwa "Penggunaan media dalam proses belajar siswa dapat membantu siswa untuk memahami materi dengan mudah dan dapat meningkatkan hasil belajar siswa".

"Buku cerita bergambar merupakan cerita yang ditulis dengan gaya bahasa ringan yang dilengkapi dengan gambar yang menjadi satu kesatuan. Tema dalam cerita bergambar juga seringkali berkenaan dengan pribadi/pengalaman pribadi sehingga pembaca mudah mengidentifikasikan dirinya melalui perasaan serta tindakan dirinya melalui perwatakan tokoh-tokoh utamanya". (Adipta et al., 2016). Dengan adanya pembelajaran daring siswa lebih mudah bosan untuk mengikuti materi pembelajaran, dengan itu adanya inisiatif dari guru untuk mengubah cara mengajar menjadi lebih menarik sangat mempengaruhi ketertarikan siswa. Peserta didik memberikan respon bahwa isi buku cerita bergambar menarik, cerita mudah dipahami, dan dapat dijadikan model dalam bersikap (Vindaswari \& Ulfah, 2018).

Kata "media" berasal dari bahasa latin yaitu "medium" yang memiliki arti sebagai pengantar atau perantara. Association for Education and Communication Technology (AECT) menyatakan bahwa media yaitu segala bentuk dan saluran yang digunakan untuk menyampaikan informasi. (Siwi Pawestri Apriliani, n.d.) "E-book adalah bentuk digital dari sebuah buku memuat informasi tertentu, format penyajian yang runtut, baik bahasanya, tinggi kadar keilmuannya, dan luas pembahasannya. E-book (electronic book) atau dikenal dengan istilah buku digital adalah versi elektronik dari buku, berisi informasi digital dapat berupa teks atau gambar" (Fahrizandi, 2019). (Kurniawati \& Koeswanti, 2020)“menunjukkan bahwa media buku cerita bergambar efektif dalam meningkatkan kemampuan dan keterampilan membaca siswa.

"Anak usia SD yakni 6-12 tahun berada pada tahap operasional konkrit. Pada tahap ini anak dapat membuat pemikiran tentang situasi atau hal konkrit secara logis. Maka dari itu, karakteristik belajar anak pada tahap ini adalah belajar melalui hal-hal yang bersifat nyata dan menghindari cara belajar menghayal atau mengira-ngira" (Aditya Dharma, 2019). Proses menumbuhkan minat baca pada anak MI/SD akan lebih efektif apabila orang tua dan guru sebagai pendidik di sekolah secara bersama-sama berperan aktif dalam membimbing anaknya. (Sumaryanti, 2020). Pentingnya buku cerita bergambar untuk menarik siswa belajar sangat cocok digunakan pada saat pandemi seperti sekarang ini. "Dengan membaca siswa akan dapat memperoleh pengetahuan yang sangat bermanfaat bagi pertumbuhan dan perkembangan daya nalar, sosial, dan emosionalnya." (Fahyuni \& Bandono, 2015). 
"Media buku digital dalam proses pembelajaran Bahasa Indonesia memiliki manfaat yang sangat besar. Dimana dengan adanya buku digital ketidakjelasan bahan yang disampaikan dapat dibantu dengan menghadirkan media buku e-book sebagai perantara. Kerumitan bahan yang akan disampaikan kepada peserta didik dapat disederhanakan dengan bantuan media buku e-book cerita bergambar. Media e-book dapat mewakili apa yang kurang mampu guru ucapkan melalui kata-kata atau kalimat tertentu. Bahkan keabstrakkan bahan dapat dikonkretkan dengan kehadiran media buku digital. Dengan demikian, peserta didik lebih mudah mencerna bahan materi daripada tanpa bantuan media buku digital." (Aprilia et al., 2017). Materi pembelajaran Bahasa Indonesia yang digunakan penulis untuk penelitian yaitu "Proses Terjadinya Hujan". Tidak menutup kemungkinan bahwa siswa cenderung tidak tertarik untuk membaca materi tentang proses terjadinya hujan hanya melalui tulisan tanpa ada gambar yang mendukung. Dalam e-book cerita bergambar tentang proses terjadinya hujan yang dikemas dengan bahasa dan gambar yang menarik akan menumbuhkan minat baca anak dan memudahkan siswa mengetahui materi proses terjadinya hujan.

Materi pembelajaran Bahasa Indonesia yang digunakan penulis untuk penelitian yaitu "Proses Terjadinya Hujan". Tidak menutup kemungkinan bahwa siswa cenderung tidak tertarik untuk membaca materi tentang proses terjadinya hujan hanya melalui tulisan tanpa ada gambar yang mendukung. (Munandar et al., 2018) mengatakan juga bahwa bahan bacaan yang menarik merupakan bahan yang dekat dengan kehidupan siswa, sedang hangat dibincangan dimasyarakat dan manfaat. Dalam e-book cerita bergambar tentang proses terjadinya hujan yang dikemas dengan bahasa dan gambar yang menarik akan menumbuhkan minat baca anak dan memudahkan siswa mengetahui materi proses terjadinya hujan.

Penulis melakukan studi pendahuluan dengan mewawancarai guru kelas 3 SD. Pada wawancara terdapat beberapa faktor yang menjadi penghambat kurangnya minat membaca siswa diantaranya guru hanya melaksanakan serta menjalankan sesuai apa yang dirancangkan pemerintah pada pembelajaran pada masa pandemi tanpa adanya beberapa inovasi yang mendukung ketika mengajar secara daring. Sekolah membutuhkan media e-book cerita bergambar untuk menunjang pembelajaran secara daring untuk meningkatkan imajinasinya, masalah lain yang menjadi kendala dalam menarik minat membaca yaitu belum adanya ketersediaan e-book untuk membaca dirumah sehingga membuat siswa kurang tertarik untuk membaca materi pembelajaran. Maka dari itu diperlukan media belajar yang cocok digunakan saat pandemic seperti sekarang ini dalam membaca.

Terdapat penelitian yang pernah dilakukan sebelumnya yang dapat membuktikan bahwa media buku cerita bergambar dapat meningkatkan minat membaca siswa SD. Seperti penelitian yang telah dilakukan oleh (Tarigan, 2018) “Tujuan penelitian ini untuk mengetahui efektivitas buku cerita bergambar untuk meningkatkan minat siswa dalam membaca siswa kelas empat sekolah dasar di Yogyakarta. Penelitian ini merupakan penelitian menggunakan eksperimen semu. Tujuan penelitian ini untuk meningkatkan minat siswa dalam membaca buku cerita bergambar secara efektif. Teknik analisis data untuk mengetahui efektivitas buku cerita bergambar menggunakan uji-t berpasangan dengan peningkatan signifikan 0,05 . Hasil dari makalah menunjukkan bahwa proses pembelajaran dengan buku cerita bergambar efektif meningkatkan minat siswa dalam membaca dengan skor -26,317 dengan probabilitas (sig) 0,000 ".

\section{METODE PENELITIAN}

Penelitian ini dirancang menggunakan jenis penelitian Research and Development $(R \& D)$. "Education research and development $(R \& D)$ is a process used to develop and validate educational products." (Borg, Walter R; Gall, 1979). "Penelitian dan pengembangan (research and development-R\&D) berasal dari dua kata yaitu penelitian (research) dan pengembangan (development)." (Rabiah, 2018). Menurut (Dwi, 2019) "Penelitian dan pengembangan atau Research and Development $(R \& D)$ adalah jenis penelitian yang digunakan untuk menghasilkan suatu produk dalam bidang pendidikan yang bertujuan untuk meningkatkan 
DOI: https://doi.org/10.31004/basicedu.v5i4.1032

kualitas pembelajaran di kelas dan pengembangannya bisa berupa media, bahan ajar maupun evaluasi pembelajaran". Produk yang akan dihasilkan dalam penelitian ini berupa e-book cerita bergambar untuk meningkatkan minat membaca siswa kelas 3 SD Tema 3 "Benda di Sekitarku" Subtema 4 "Keajaiban Perubahan Wujud di Sekitarku".

Penelitian ini dibuat oleh peneliti berdasarkan prosedur penelitian 10 tahapan Borg and Gall dengan modifikasi menjadi lima tahap yaitu: 1) Penelitian dan pengumpulan data, pada tahap ini dilakukan survei lapangan dan analisis data, 2) Perencanaan, pada tahap ini peneliti melakukan penyusunan e-book cerita bergambar sesuai teori-teori yang telah diuraikan dan menentukan desain $e$-book cerita bergambar sesuai dengan tema dan subtema. 3) Pengembangan draf produk, pada tahap ini menggunakan 4 tahapan dari Thiagarajan, tahapan penelitian pengembangan model 4D (four-D model) ini terdiri dari pendefinisian (define), tahap perancangan (design), tahap pengembangan (develop), dan tahap uji coba (disseminate). 4) Penyempurnaan produk akhir, pada tahap ini memuat tahap penyempurnaan produk akhir hasil uji coba ahli materi dan ahli media, disatukan untuk merevisi sehingga menjadi produk e-book cerita bergambar proses terjadinya hujan yang sempurna. 5)Diseminasi dan Implementasi, pada tahap ini produk e-book cerita bergambar sudah siap untuk diimplementasikan.

\section{Analisis data}

Teknik data dalam uji validasi menggunakan teknik deskriptif persentase dan kategoris guna mengembangkan kelayakan media e-book cerita bergambar. Mula-mula skor tersebut dipersentase dengan menggunakan rumus:

$\mathrm{AP}=\frac{\text { Skor Aktual }}{100 \%} \mathrm{X}$

Keterangan:

AP : Angka Persentase

Skor Aktual : : Skor yang diberikan oleh validator ahli

Skor Ideal $\quad$ : Skor maksimal hasil kali antara jumlah item dengan skor maksimal masing-masing item

Angka persentase tersebut selanjutnya dikelompokkan menjadi lima kategori berikut ini:

Tabel 1. Kategori Uji Validasi

\begin{tabular}{ll}
\hline Interval & Kategori \\
\hline $81-100 \%$ & Sangat Tinggi \\
\hline $61-80 \%$ & Tinggi \\
\hline $41-60 \%$ & Cukup \\
\hline $21-40 \%$ & Rendah \\
\hline $1-20 \%$ & Sangat Rendah \\
\hline
\end{tabular}

\section{HASIL DAN PEMBAHASAN}

Hasil studi pendahuluan yang dilakukan melalui wawancara terhadap guru kelas 3 SD Negeri 1 Cawas, Kecamatan Cawas, Kabupaten Klaten. Media pembelajaran guru kurang menarik bagi siswa yaitu guru masih menggunakan media cetak berupa buku teks saja sehingga membuat siswa kurang bersemangat dan mudah bosan saat diminta untuk membaca. Dampak dari pembelajaran daring selama pandemic Covid-19 membuat anak bosan membaca materi dengan buku cetak saja sehingga mengakibatkan siswa kurang memahami materi pembelajaran. 

Membaca Siswa di Sekolah Dasar - Novita Agnes Putrislia, Gamaliel Septian Airlanda

DOI: https://doi.org/10.31004/basicedu.v5i4.1032

Melihat kebutuhan yang diperlukan SD Negeri 1 Cawas, penulis mengembangkan media e-book cerita bergambar yang bertujuan meningkatkan minat membaca bagi siswa dalam pembelajaran daring selama pandemi. Hasil pengembangan produk yaitu e-book cerita bergambar dengan judul "Pengembangan E-Book Cerita Bergambar Proses Terjadinya Hujan untuk Meningkatkan Minat Membaca Siswa Kelas III SD". Media pembelajaran ini memuat materi Bahasa Indonesia untuk kelas 3 Tema 3 "Benda di Sekitarku".

Sub tema 4 "Keajaiban perubahan wujud di sekitarku" Pembelajaran 5. Pada materi Bahasa Indonesia yaitu tentang proses terjadinya hujan. Bagian sebelum memulai materi dalam penyusunan e-book cerita bergambar memuat judul, kata pengantar dan pengenalan tokoh. Kata pengantar berisi perkataan penulis tentang tujuan yang hendak dicapai dalam kegiatan pembelajaran menggunakan $e$-book cerita bergambar dan sasaran pengguna $e$-book cerita bergambar. Pada bagian pendahuluan $e$-book cerita bergambar juga memuat pengenalan tokoh untuk membantu siswa memahami tokoh dalam cerita. Produk e-book cerita bergambar untuk meningkatkan minat membaca siswa kelas 3 SD ini didesain dan dikembangkan dengan memuat gambar berwarna dan cerita yang menarik sesuai dengan kehidupan sehari-hari sehingga diharapkan dapat menarik minat membaca siswa dalam pembelajaran daring pada masa pandemi Covid-19. Bagian setelah pemberian materi memuat pertanyaan yang dapat digunakan siswa untuk dapat menganalisis cerita dalam $e$ book cerita bergambar, identitas penulis yang berisi biodata penulis. Berikut adalah tampilan dari media pembelajaran $e$-book cerita bergambar.

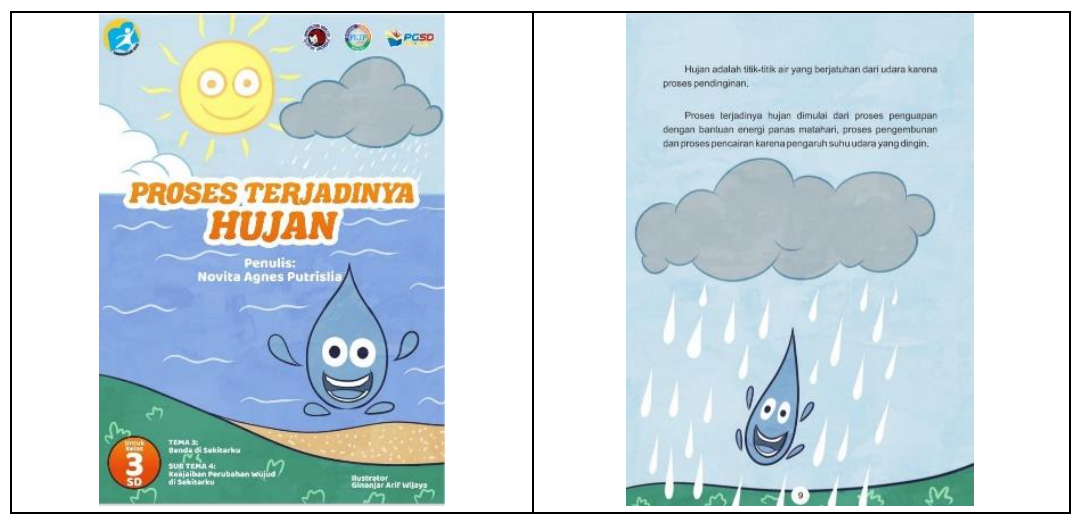

Gambar 1. Tampilan Cover Cerita Bergambar

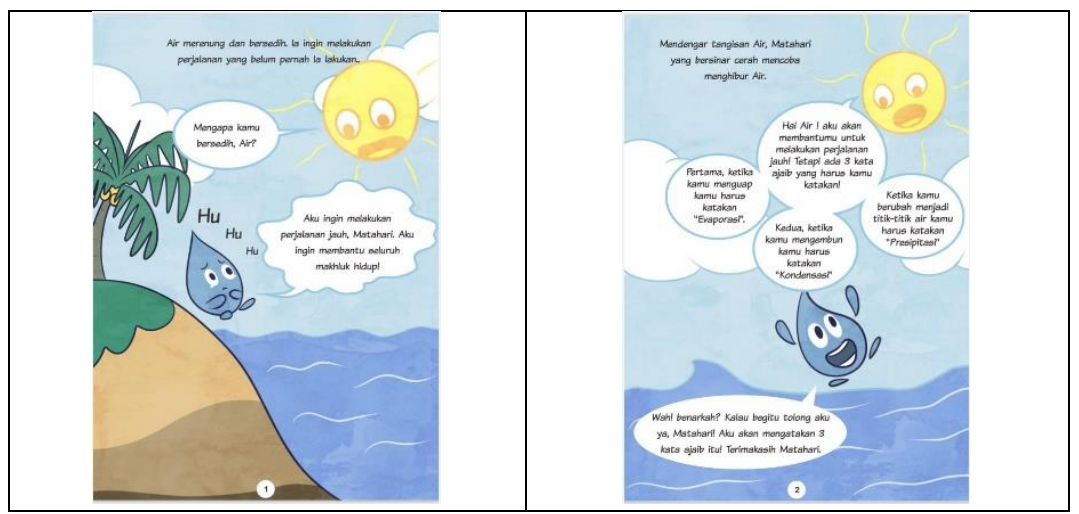


2041 Pengembangan E-Book Cerita Bergambar Proses Terjadinya Hujan untuk Meningkatkan Minat Membaca Siswa di Sekolah Dasar - Novita Agnes Putrislia, Gamaliel Septian Airlanda

DOI: https://doi.org/10.31004/basicedu.v5i4.1032

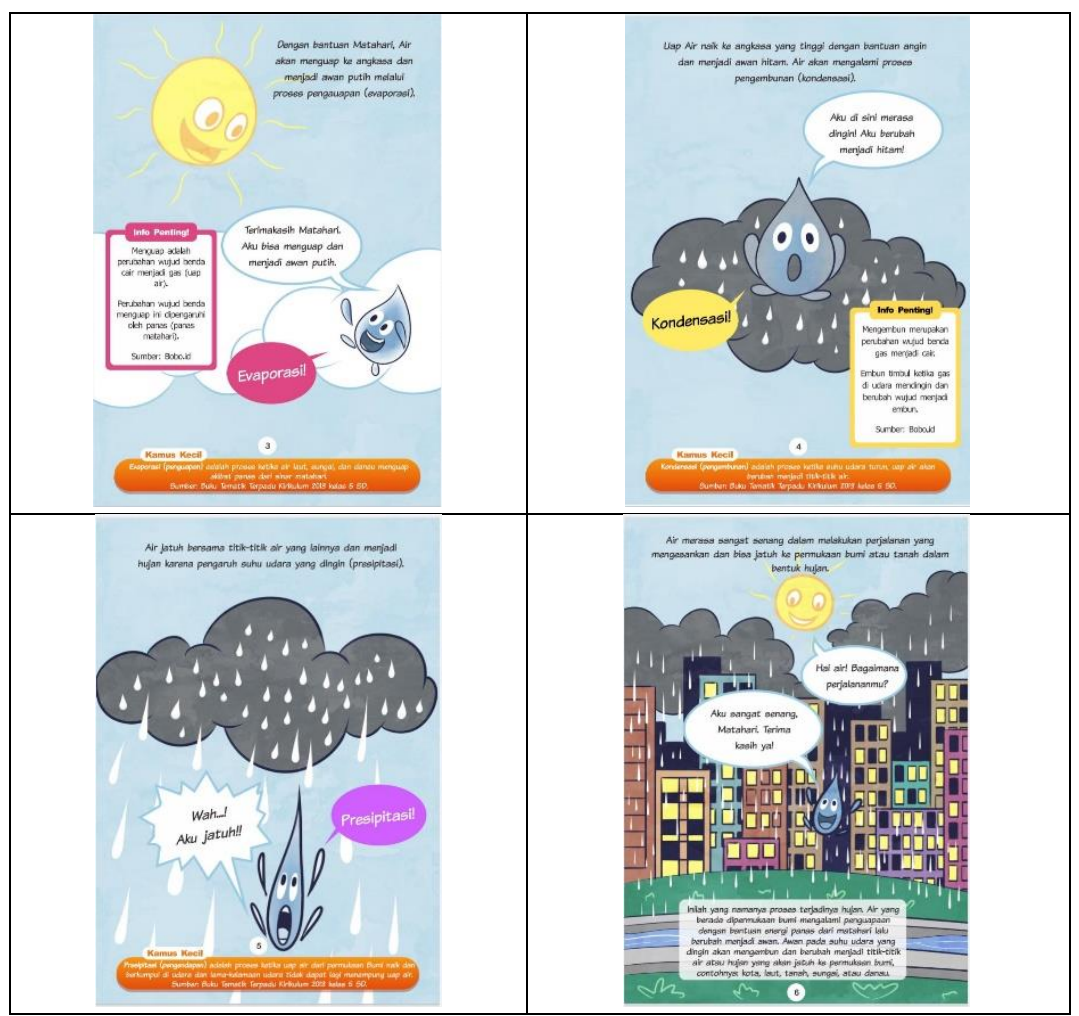

Gambar 2. Materi Proses Terjadinya Hujan

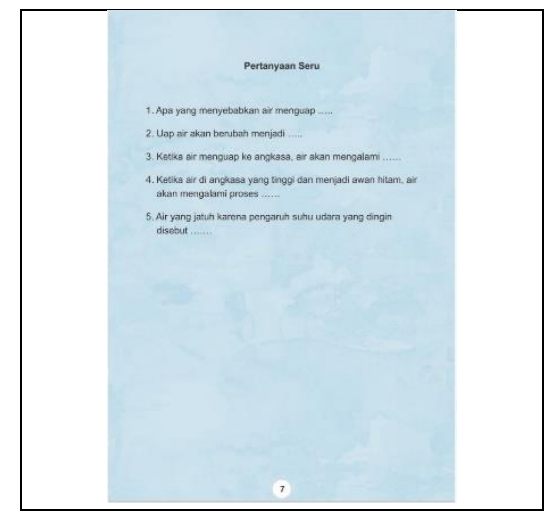

Gambar 3. Pertanyaan Seru dalam Cerita

Setelah draft produk dikembangkan tahap selanjutnya adalah menguji produk oleh tiga dosen uji ahli materi dan tiga dosen uji ahli media. Pada ahli tersebut adalah Dosen PGSD, Dosen Pendidikan Sejarah, dan Dosen FTI Universitas Kristen Satya Wacana Salatiga. Berikut adalah hasil validasi produk oleh ahli materi dan ahli media.

Tabel 2. Hasil Validasi Ahli Materi

\begin{tabular}{ccccccc}
\hline No & Ahli Materi & Skor Ideal & Skor Aktual & $\begin{array}{c}\text { Angka } \\
\text { Persentase }\end{array}$ & \multicolumn{2}{c}{ Keterangan } \\
\hline 1 & Ahli Materi 1 & 65 & 61 & $93 \%$ & $\begin{array}{l}\text { "Sangat Tinggi" dengan } \\
\text { interval 81 sampai 100\%. }\end{array}$ \\
\hline 2 & Ahli Materi 2 & 65 & 60 & $92 \%$ & $\begin{array}{l}\text { "Sangat Tinggi" dengan } \\
\text { interval 81 sampai 100\%. }\end{array}$
\end{tabular}


2042 Pengembangan E-Book Cerita Bergambar Proses Terjadinya Hujan untuk Meningkatkan Minat Membaca Siswa di Sekolah Dasar - Novita Agnes Putrislia, Gamaliel Septian Airlanda

DOI: https://doi.org/10.31004/basicedu.v5i4.1032

\begin{tabular}{|c|c|c|c|c|c|}
\hline 3 & Ahli Materi 3 & 65 & 52 & $80 \%$ & $\begin{array}{l}\text { "Tinggi" dengan interval } 61 \\
\text { sampai } 80 \% \text {. }\end{array}$ \\
\hline
\end{tabular}

Sesuai dengan tabel 1 hasil penilaian dari ahli materi diatas terlihat bahwa penilaian dari ahli materi pertama mendapat angka persentase 93\% dengan kategori "Sangat Tinggi" dengan interval 81 sampai 100\%, ahli materi kedua mendapat angka persentase 92\% dengan ketegori "Sangat Tinggi" dengan interval 81 sampai 100\%, dan ahli materi 3 mendpaat angka persentase 80\% dengan kategori "Tinggi" dengan interval 61 sampai $80 \%$. Aspek yang divalidasi oleh ahli materi meliputi: 1) Materi Bahasa Indonesia pada cerita Proses terjadinya hujan, 2) Kebahasaan yang dipakai dalam cerita di e-book "Proses Terjadinya Hujan" ini, dan 3) Ilustrasi yang digunakan penulis untuk menunjang isi materi dalam e-book ini. Dengan ini dapat disimpulkan bahwa produk e-book cerita bergambar "Proses Terjadinya Hujan" dapat digunakan untuk menunjang pembelajaran Bahasa Indonesia khususnya dalam membaca di SD Negeri 1 Cawas.

Tabel 3. Hasil Validasi Ahli Media

\begin{tabular}{cccccc}
\hline No & Ahli Media & Skor Ideal & Akor Aktual & $\begin{array}{c}\text { Angka } \\
\text { Persentase }\end{array}$ & \multicolumn{2}{c}{ Keterangan } \\
\hline 1 & Ahli Media 1 & 50 & 44 & $88 \%$ & $\begin{array}{l}\text { "Sangat Tinggi” dengan } \\
\text { interval 81 sampai 100\%. }\end{array}$ \\
\hline 2 & Ahli Media 2 & 50 & 50 & $100 \%$ & $\begin{array}{l}\text { "Sangat Tinggi” dengan } \\
\text { interval 81 sampai 100\%. }\end{array}$ \\
\hline 3 & Ahli Media 3 & 50 & 50 & $100 \%$ & $\begin{array}{l}\text { "Tinggi” dengan interval 61 } \\
\text { sampai 80\%. }\end{array}$ \\
& & & &
\end{tabular}

Sesuai dengan tabel 2 hasil penilaian dari ahli media diatas terlihat bahwa penilaian dari ahli media pertama mendapat angka persentase 88\% dengan kategori "Sangat Tinggi" dengan interval 81 sampai 100\%, ahli media kedua mendapat angka persentase $100 \%$ dengan ketegori "Sangat Tinggi" dengan interval 81 sampai $100 \%$, dan ahli media 3 mendapat angka persentase 100\% dengan kategori "Tinggi" dengan interval 61 sampai $80 \%$. Aspek yang divalidasi oleh ahli media meliputi: 1) Tampilan dalam e-book cerita bergambar "Proses Terjadinya hujan", 2) Isi e-book dengan ilustrasi yang digunakan, 3) Ilustrasi gambar yang dapat menarik siswa untuk membaca. Dengan ini dapat disimpulkan bahwa produk e-book cerita bergambar "Proses Terjadinya Hujan" dapat digunakan untuk menunjang pembelajaran Bahasa Indonesia khususnya dalam membaca di SD Negeri 1 Cawas.

Ahli materi dan ahli media pada produk e-book cerita bergambar memberikan saran yaitu materi tentang proses terjadinya hujan dan ilustrasi dalam cerita. Walaupun masih ada yang bisa diperbaiki lagi namun, kategori $e$-book cerita bergambar "Proses Terjadinya Hujan" menunjukkan layak untuk digunakan.

\section{Keterbatasan Penelitian:}

Dalam melakukan penelitian pengembangan e-book cerita bergambar menggunakan model pengembangan 4-D ini peneliti mengalami beberapa keterbatasan, antara lain:

1. Penelitian pengembangan model desain pembelajaran hanya dilakukan sampai dengan uji validasi saja, tidak diujikan secara terbatas dan luas.

2. Hasil dari e-book ini akan diberikan kepada siswa kelas 3 SD Negeri 1 Cawas dengan link.

3. Pengembangan $e$-book cerita bergambar ini hanya digunakan untuk materi proses terjadinya hujan saja. 
2043 Pengembangan E-Book Cerita Bergambar Proses Terjadinya Hujan untuk Meningkatkan Minat Membaca Siswa di Sekolah Dasar - Novita Agnes Putrislia, Gamaliel Septian Airlanda

DOI: https://doi.org/10.31004/basicedu.v5i4.1032

\section{KESIMPULAN}

Produk yang dihasilkan adalah e-book cerita bergambar. Media pembelajaran ini memuat materi pembelajaran Bahasa Indonesia untuk kelas 3 SD Tema 3 Sub Tema 4. Materi Bahasa Indonesia yaitu membahas tentang proses terjadinya hujan. Hasil dari validasi ahli materi pertama memperoleh angka persentase 93\% dan tergolong dalam interval $81-100 \%$ sehingga termasuk dalam kategori "Sangat Tinggi". Hasil dari validasi ahli materi kedua memperoleh angka persentase 92\% dan tergolong dalam interval 81$100 \%$ sehingga termasuk dalam kategori "Sangat Tinggi". Hasil dari validasi ahli materi ketiga memperoleh angka persentase $80 \%$ dan tergolong dalam $61-80 \%$ sehingga termasuk dalam kategori "Tinggi". Hasil dari validasi ahli media pertama memperoleh angka persentase $88 \%$ dan tergolong dalam interval $81-100 \%$ sehingga termasuk dalam kategori "Sangat Tinggi". Hasil dari validasi ahli media kedua memperoleh angka persentase $100 \%$ dan tergolong dalam interval $81-100 \%$ sehingga termasuk dalam kategori "Sangat Tinggi". Hasil dari validasi ahli media ketiga memperoleh angka persentase $100 \%$ dan tergolong dalam interval 81 100\% sehingga termasuk dalam kategori "Sangat Tinggi". Hasil dari kategori tersebut dapat dinyatakan bahwa e-book cerita bergambar yang berjudul "Proses Terjadinya Hujan" untuk meningkatkan minat membaca siswa kelas 3 SD layak untuk digunakan.

\section{DAFTAR PUSTAKA}

Achmad, A., Wahyu, A., \& Khotimah, K. (2018). Pengembangan Media Buku Cerita Elektronik Materi Hak Dan Kewajiban Mata Pelajaran Ppkn Siswa Kelas V Sdn 1 Sungonlegowo Gresik. Jurnal Mahasiswa Teknologi Pendidikan, 9, 1-6. Https://Jurnalmahasiswa.Unesa.Ac.Id/Index.Php/Jmtp/Article/View/28287

Adipta, H., Hasanah, M., Dasar, P., \& Malang, P. N. (2016). Pemanfaatan Buku Cerita Bergambar. 989-992.

Aditya Dharma, I. M. (2019). Pengembangan Buku Cerita Anak Bergambar Dengan Insersi Budaya Lokal Bali Terhadap Minat Baca Dan Sikap Siswa Kelas V Sd Kurikulum 2013. Journal For Lesson And Learning Studies, 2(1), 53-63. Https://Doi.Org/10.23887/Jlls.V2i1.17321

Aprilia, T., Sunardi, S., \& Djono, D. (2017). Penggunaan Media Sains Flipbook Dalam Pembelajaran IPA Di Sekolah Dasarr. Teknodika, 15(2), 75. Https://Doi.Org/10.20961/Teknodika.V15i2.34749

Borg, Walter R; Gall, M. D. (1979). Educational Research. Longman Inc.

Dafit, F. (2017). Pengaruh Model Pembelajaran Multiliterasi Terhadap Kemampuan Membaca Siswa Sekolah Dasar. Jurnal Inovasi Pendidikan Dan Pembelajaran Sekolah Dasar, 1(1), 87-100. Https://Doi.Org/10.24036/Jippsd.V1i1.7937

Dwi, M. E. (2019). Research And Development (R\&D): Inovasi Produk Dalam Pembelajaran. Researchgate, August, 1-8. Https://Www.Researchgate.Net/Publication/335227473

Fahrizandi, F. (2019). Mengenal E-Book Di Perpustakaan. Pustabiblia: Journal Of Library And Information Science, 3(2), 141-157. Https://Doi.Org/10.18326/Pustabiblia.V3i2.141-157

Fahyuni, E. ., \& Bandono, A. (2015). Pengembangan Media Cerita Bergambar Sebagai Upaya Meningkatkan Kemampuan Membaca Siswa Sekolah Dasar. Jurnal Kependidikan Dan Keislaman, 14(1), 1-17.

Farid Ahmadi. (2010). Meningkatkan Minat Membaca Siswa Sekolah Dasar Dengan Metode Glenn Doman Berbasis Multimedia. Jurnal Penelitian Pendidikan Unnes, 64-71.

Hapsari, Y. I., Purnamasari, I., \& Purnamasari, V. (2019). Minat Baca Siswa Kelas V Sd Negeri Harjowinangun 02 Tersono Batang. Indonesian Journal Of Educational Research And Review, 2(3), 371. Https://Doi.Org/10.23887/Ijerr.V2i3.22634

Herlina, V., Yarmi, G., \& Yuliati, S. R. (2019). Pengembangan Buku Cerita Anak Digital Berbasis Literasi Digital Pada Siswa Kelas V Sekolah Dasar. Dinamika Bahasa Sekolah Dasar, 1(1), 1-13. 
2044 Pengembangan E-Book Cerita Bergambar Proses Terjadinya Hujan untuk Meningkatkan Minat Membaca Siswa di Sekolah Dasar - Novita Agnes Putrislia, Gamaliel Septian Airlanda

DOI: https://doi.org/10.31004/basicedu.v5i4.1032

Https://Journal.Pgsdfipunj.Com/Index.Php/Bahasa/Article/View/117

Kurniawati, R. T., \& Koeswanti, H. D. (2020). Pengembangan Media Buku Cerita Bergambar Untuk Meningkatkan Kemampuan Membaca Siswa Kelas 1 Sekolah Dasar. DIDAKTIKA TAUHIDI: Jurnal Pendidikan Guru Sekolah Dasar, 7(1), 29. Https://Doi.Org/10.30997/Dt.V7i1.2634

Laily, I. F. (2014). Hubungan Kemampuan Membaca Pemahaman Dengan Kemampuan Memahami Soal Cerita Matematika Sekolah Dasar. Eduma: Mathematics Education Learning And Teaching, 3(1). Https://Doi.Org/10.24235/Eduma.V3i1.8

Munandar, A., Mulyadiprana, A., \& Apriliya, S. (2018). Pedadidaktika: Jurnal Ilmiah Pendidikan Guru Sekolah Dasar Penggunaan Buku Cerita Anak Berbasis Kearifan Lokal Mendong Tasikmalaya Di Sekolah Dasar. 5(2), 152-162.

Rabiah, S. (2018). Penggunaan Metode Research And Development Dalam Penelitian Bahasa Indonesia Di Perguruan Tinggi. April 2015, 1-7. Https://Doi.Org/10.31227/Osf.Io/Bzfsj

Ratnasari, E. M., \& Zubaidah, E. (2019). Pengaruh Penggunaan Buku Cerita Bergambar Terhadap Kemampuan Berbicara Anak. Scholaria: Jurnal Pendidikan Dan Kebudayaan, 9(3), 267-275. Https://Doi.Org/10.24246/J.Js.2019.V9.I3.P267-275

Siwi Pawestri Apriliani, E. H. R. (N.D.). Jurnal Basicedu. Jurnal Basicedu, 3(1), 208-213.

Sumaryanti, L. (2020). Menumbuhkan Minat Baca Anak MI / SD Dengan Media Buku Bergambar Seri Pendidikan Merupakan Kebutuhan Primer Untuk Menjamin Kelangsungan Hidup Bangsa Dan Negara . Pendidikan Adalah Sarana Untuk Meningkatkan Dan Mengembangkan Sumber Daya Manusia Guna Mewujud. Al-Asasiyya: Journal Basic Of Education: Journal Basic Of Education, 4(2), 173-183.

Vindaswari, R. F., \& Ulfah, A. (2018). Pengembangan Buku Cerita Anak Bergambar Berbasis Nilai-Nilai Kepedulian Bagi Peserta Didik Kelas 2 Sekolah Dasar. Jurnal Fundadikdas (Fundamental Pendidikan Dasar), 1(3), 148. Https://Doi.Org/10.12928/Fundadikdas.V1i3.661 